Terbit online pada laman web jurnal : http://ojs.unitas-pdg..ac.id/

Jurnal Manajemen dan Kewirausahaan

\begin{tabular}{l|l|l} 
ISSN (Print) 2086-5031 | ISSN (Online) 2615-3300 | DOI 10.31317 \\
\hline
\end{tabular}

\title{
Reaksi Pasar Modal terhadap Peristiwa Ekstrim dan Radikalisme (Studi Pasca Serangan Teroris di Surabaya)
}

\author{
Sari Octavera, Febri Rahadi \\ Universitas Dharma Andalas, Jl. Sawahan No.103, Sawahan Timur, Simpang Haru, Kota Padang, Sumatera Barat 25000, Indonesia
}

INFORMASI ARTIKEL

Sejarah Artikel:

Diterima Redaksi: 11 Januari 2019

Revisi Akhir: 05 Februari 2019

Diterbitkan Online: 07 Februari 2019

\section{KATA KUNCI}

Investor Sentiment, Firm's Fundamental;

Overreaction

KORESPONDENSI

Telepon:

E-mail: sarioctavera@gmail.com,

febri@unidha.ac.id

\begin{abstract}
A B S T $\mathbf{T} \mathbf{R}$ A $\mathbf{C}$ T
Extreme events of terrorism attacks namely the Surabaya Bomb on May 13, 2018. Analysis of abnormal return is carried out to compare the reactions that occur before and after the event. The results of two different statistical tests on average indicate that there is positive postevent sentiment. This implies that investors do not feel that terrorist attacks are a significant disruption to their investment. Comparison between the pre and post-bomb days shows that the AAR of the second day of the pre-event had a significant difference with the AAR on the 4 th day after the incident indicating that the bombing event not included as bad news for capital market players. The investor's reaction to the bomb attack was carried out by looking at the value of Cumulative Average Abnormal Return (CAAR) from post-bomb attack data and showing that manufacturing stock returns tend to be stable, with insignificant increases and decreases at $t+1$ to $t+5$, which indicates that there is no evidence of post-event overreaction.
\end{abstract}

\section{PENDAHULUAN}

Fluktuasi harga saham di Pasar Modal menjadi perhatian penting bagi investor. Fluktuasi harga ini dapat disebabkan oleh banyak hal terkait dengan informasi yang diterima investor atas dasar peristiwa atau kejadian-kejadian. Sentimen investor muncul tidak hanya dari kejadian atau peristiwa ekonomi saja. Perubahan iklim sosial-politik suatu negara juga akan mempengaruhi sentimen investor dalam pengambilan keputusan investasi.

Pembangunan ekonomi yang berkelanjutan di suatu negara senantiasa dipengaruhi oleh kondisi geopolitik negara tersebut. Fenomena terkini adalah maraknya tindakan terorisme yang terjadi di dalam 
negeri bahkan telah menjadi fenomena global yang meresahkan. Johnston dan Nedelescu (2005) memberikan penekanan bahwasanya keyakinan investor dapat serta merta rusak diakibatkan oleh peristiwa yang terkait dengan terorisme. Didalam negeri, aksi terorisme terbukti memberikan dampak negatif di pasar modal dimana Indeks Harga Saham Gabungan (IHSG) mengalami penurunan hingga $1,24 \%$ di selama sesi perdagangan awal dan terus merosot hingga $1,72 \%$ pada saat penutupan sesi. Mayoritas saham mengalami penurunan, tercatat 214 emiten merasakan dampak penurunan harga saham di bursa paska peristiwa pengeboman di kawasan Sarinah pada minggu kedua Januari 2016. (finance.detik.com, 14 januari 2016).

Penelitian ini berupaya menangkap reaksi dan sentimen investor terkait dengan tindakan teror yang dilakukan dalam bentuk pemboman yang terjadi di beberapa titik di Surabaya pada tanggal 13 Mei 2018. Penelitian ini menggunakan pendekatan event study untuk menangkap esensi dari reaksi pasar terhadap tindakan terorisme melalui Abnormal Return, Average Abnormal Return dan Cumulative Average Abnormal Return. Metode ini serupa dengan penelitian yang dilakukan oleh Utama dan Hapsari (2012) dengan pendekatan jenis industri. Lebih lanjut, penelitian ini juga mengaplikasikan metode penelitian yang dilakukan Handoko dan Supramono (2016) yang meneliti overreaction pada pasar modal mengikuti kejadian terorisme yaitu Bom Sarinah pada 14 Januari 2016.

Penelitian ini bertujuan untuk menjelaskan efek dari kejadian ektrim terorisme berupa serangan Bom di Surabaya pada 13 Mei 2018. Secara umum, penelitian ini diharapkan dapat memberikan informasi yang memadai terkait dengan efek dari serangan terorisme terhadap reaksi pasar, dan dapat dijadikan sebagai referensi dalam pengambilan keputusan investasi oleh investor. Secara khusus, penelitian ini diharapkan mampu memberikan manfaat kepada institusi dalam mengembangkan materi ajar keputusan investasi dan manajemen keuangan.

\section{Study Peristiwa (Event Study)}

Penelitian ini menggunakan studi peristiwa (event study). Studi peristiwa (event study) merupakan studi yang mempelajari reaksi pasar terhadap suatu peristiwa (event), informasinya dipublikasikan sebagai suatu pengumuman. Event study dapat digunakan untuk menguji kandungan 
informasi (information content) dari suatu pengumuman (Hartono, 2014). Harga sekuritas akan berubah jika pengumuman tersebut mengandung informasi, sementara sentimen investor diukur dengan menggunakan return atau abnormal return. Jika tidak mengandung informasi makan tidak akan memberikan return atau abnormal return kepada pasar.

Mackinlay (1997) menyebutkan bahwa ada langkah- langkah yang harus diperhatikan dalam melakukan event study diantaranya adalah:

1. Mendefinisikan kejadian yang diminati yaitu berupa informasi yang tersedia di pasar.

2. Membangun teori yang mampu memberikan alasan atau menjelaskan respon keuangan terhadap kejadian tersebut.

3. Mengidentifikasi tanggal kejadian (event date).

4. Memilih event windows yang cocok sesuai dengan justifikasi jaraknya.

5. Menyesuaikan perusahaan-perusahaan yang mengalami kejadian tersebut.

6. Menghitung abnormal return selama event windows dan menguji tingkat signifikansinya.

\section{METODE PENELITIAN}

Penelitian ini menggunakan data sekunder yang diperoleh dari www.idx.co.id, www.finance.yahoo.com yaitu data keuangan perusahaan manufaktur yang terdaftar di Bursa Efek Indonesia, dan data informasi melalui media cetak maupun online yang memberikan informasi peristiwa serangan teroris di Surabaya pada hari Minggu tanggal 13 Mei 2018.

\section{Pengukuran}

Dampak dari peristiwa serangan teroris pada event date tersebut terhadap sentiment investor di pasar modal dapat dilihat dengan Average Abnormal Return (AAR) pada saham perusahaan manufaktur. Analisis terhadap overreaction dilakukan dengan melihat nilai CAAR pada paska kejadian dan memperhatikan kondisi yang menunjukkan overreaction. Berdasarkan pengamatan tersebut, apabila abnormal return setelah event date signifikan dan mengalami perubahan ke arah yang berlawanan atau ditandai dengan adanya pembalikan harga maka terjadi overreaction.

\section{Populasi dan Metode Sampling}

Penelitian ini akan melihat reaksi pasar terhadap peristiwa serangan teroris di Surabaya pada hari Minggu Tanggal 13 
Mei 2018 untuk semua perusahaan manufaktur yang terdaftar di Bursa Efek Indonesia (BEI). Sektor manufaktur merupakan sektor industri dengan emiten terbanyak di pasar modal. Selain itu, Surabaya juga merupakan sentra industri manufaktur di Indonesia.

Tabel 1. Data Perusahaan Manufaktur yang Terdaftar di BEI pada Mei 2018

\begin{tabular}{cllc}
\hline No & \multicolumn{1}{c}{ Sektor } & \multicolumn{1}{c}{ Sub Sektor } & Jumlah \\
\hline 1 & Industi Dasar dan Kimia & Semen & 6 \\
& & Keramik, Porselen dan Kaca & 7 \\
& & Logam dan sejenisnya & 10 \\
& Kimia & 11 \\
& & Plastik dan Kemasan & 10 \\
& & Pakan Ternak & 4 \\
& & Kayu dan Pengolahannya & 2 \\
& & Pulp dan Kertas & 9 \\
\hline 2 & Aneka Industri & Mesin dan Alat Berat & 3 \\
& & Otomotif dan Komponen & 13 \\
& & Tekstil dan Garment & 19 \\
& & Alas Kaki & 2 \\
& & Kabel & 6 \\
& & Elektronika & 1 \\
\hline 3 & Industri Barang Konsumsi & Makanan Dan Minuman & 18 \\
& & Rokok & 4 \\
& & Farmasi & 11 \\
& & Kosmetik dan Barang Keperluan Rumah & 6 \\
& & Tangga & \\
& & &
\end{tabular}

Metode pengambilan sampel dilakukan dengan menggunakan metode purposive sampling. Adapun kriteria pengambilan sampel yang digunakan dalam penelitian ini adalah sebagai berikut:

1. Perusahaan manufaktur yang terdaftar di BEI selama periode penelitian dan mempublikasikan laporan tahunan lengkap berturut-turut selama periode penelitian.

2. Tidak melakukan pembagian dividen, stock split, melakukan akuisisi dan merger selama periode penelitian agar hasil penelitian ini memang benar-benar melihat pengaruh yang terjadi terhadal return saham ini dari peristiwa aksi

eroris pada Minggu tanggal 13 Mei 2018 di Surabaya tersebut saja tanpa pengaruh 
dari kebijakan yang dilakukan oleh perusahaan.

Event windows yang digunakan adalah 5 hari sebelum tanggal peristiwa (event date) dan 5 hari setelah tanggal peristiwa, yaitu pada Minggu 13 Mei 2018.

\section{Tahapan Analisa Data}

Tahapan analisis dilakukan dalam penelitian ini sebagai berikut:

Pertama, menentukan event date yaitu hari pada saat kejadian 13 Mei 2018 $(\mathrm{t}=0)$ hingga 25 Mei $2018(\mathrm{t}=+5)$. Berbeda dengan event study terhadap peristiwa pengumuman dikeluarkan oleh perusahaan atau dikenal corporate action atau pengumuman yang berasal dari luar peristiwa perusahaan seperti pengumuman reshuffle kabinet yang dilakukan oleh Supramono et.al (2017), serangan teroris tidak memiliki kemungkinan kebocoran informasi (leakage information), sehingga $\mathrm{t}=0$ ditetapkan sebagai awal dari event windows dan periode estimasi selama 5 hari sebelum event date.

Kedua, melakukan pengujian hipotesis dengan melibatkan langkah-langkah analisis sebagai berikut:

(1) Menghitung return saham

$$
\begin{gathered}
R j, t=\frac{P j, t-P j, t-1}{P j, t-1} \\
\text { Rj,t }=\begin{array}{l}
\text { Pendapatan Aktual saham j pada } \\
\text { bulan } \mathrm{t}
\end{array}
\end{gathered}
$$

$\mathrm{Pj}, \mathrm{t}=$ Harga saham $\mathrm{j}$ pada bulan $\mathrm{t}$

$\mathrm{Pj}, \mathrm{t}-\mathrm{1}=$ Harga saham $\mathrm{j}$ pada bulan $\mathrm{t}-1$

(2) Menghitung return pasar (Rm)

$$
R m, t=\frac{I H S G t-I H S G t-1}{I H S G t-1}
$$

Rmt = Pendapatan pasar hari $\mathrm{t}$

IHSGt = Indeks Harga Saham pada bulan $\mathrm{t}$

HSGt-1 = Indeks Harga Saham pada bulan $\mathrm{t}-1$

(3) Menghitung abnormal return merupakan selisih antara actual return dengan expected return. Pada penelitian ini expected return dihitung dengan menggunakan metode sesuaian pasar (market adjusted model).

$$
\begin{aligned}
& \mathrm{R} \mathrm{jt}=\alpha \mathrm{j}+\beta \mathrm{j} \mathrm{Rmt} \\
& \text { ARjt } \quad=R j t-\alpha j+\beta j R m t \\
& \mathrm{R} \mathrm{jt}=\text { Expected return saham }
\end{aligned}
$$
ARjt = abnormal return saham untuk perusahaan $\mathrm{j}$ pada periode ke- $t$

(4) Menguji apakah peristiwa serangan terorisme yang terjadi tersebut memberikan dampak terhadap ratarata abnormal return pada saham perusahaan manufaktur pada saat event windows, $\mathrm{t}$ statistik (t hitung) untuk masing-masing periode dihitung dengan menggunakan AAR, 
dan standar deviasi AAR, sebagai berikut

$$
\text { AARnt }=\frac{\sum A R j t}{N}
$$

Standar deviasi AAR dihitung dengan rumus, yaitu:

$$
\begin{aligned}
& \text { ane }=\sqrt{\frac{\sum \alpha^{2} i e}{N}} \\
\mathrm{~N} \quad & \text { Jumlah saham yang } \\
& \text { menjadi sampel } \\
\text { ane } \quad & \text { Nilai standar deviasi AR } \\
& \text { pada periode estimasi }
\end{aligned}
$$

Sehingga, $t$ statistik ( $\mathrm{t}$ hitung) dinyatakan dengan rumus, yaitu:

$$
\mathrm{t} \text { hitung }=\frac{A A R n t}{\alpha \mathrm{ne}}
$$

(5) Menguji apakah peristiwa serangan terorisme yang terjadi tersebut memberikan dampak terhadap ratarata abnormal return pada kelompok perusahaan dengan fundamental baik dan yang kurang baik selama event windows, $\mathrm{t}$ statistik (t hitung) untuk masing-masing periode dihitung dengan menggunakan AAR, dan standar deviasi AAR sama seperti dengan langkah (4);

(6) Menganalisis pembalikan harga yang terjadi melalui grafik Cumulative Average Abnormal Return (CAAR) dan nilai AAR pada hari setelah peristiwa apakah signifikan dan bernilai positif.

Tabel 2. Data Statistika Deskriptif

\begin{tabular}{lcccc}
\hline & \multicolumn{4}{c}{ Abnormal Return } \\
\cline { 2 - 5 } & Min & Max & Mean & Std Dev \\
\hline Sebelum Event Windows & -59.9616 & 0.63619 & -0.46532 & 3.8965 \\
\hline Setelah Event Windows & -30.8998 & 239.5305 & 0.30657 & 11.4507 \\
\hline Sumber : Olah Data, Excel 2018 & &
\end{tabular}

\section{HASIL DAN PEMBAHASAN}

\section{Analisa Statistika Deskriptif}

Data yang di analisa adalah data Abnormal Return (AR) berupa nilai maksimum, minimum, rata-rata dan standar deviasi. Pengujian dilakukan 5 hari sebelum event dan 5 hari setelah event. Abnormal return dari saham emiten manufaktur cenderung lebih negatif pra peristiwa bom, dan mencatatkan abnormal return yang sangat positif paska bom. Hal ini mengimplikasikan bahwa tingkat pengembalian dari saham perusahaan manufaktur secara rata-rata cenderung

positif paska terjadinya peristiwa pemboman di Surabaya. Deviasi yang lebih besar paska kejadian bom 
menunjukkan bahwa variasi tingkat pengembalian dari sampel perusahaan manufaktur cenderung variatif.

Sentimen Pasar Modal Terhadap Peristiwa Serangan Bom di Surabaya pada 13 Mei 2018

Pengujian selanjutnya adalah menguji perbedaan dua rata-rata sampel Average Abnormal Return. Berdasarkan hasil uji statistik, diperoleh hasil berikut ini:

Tabel 3. Pengujian AAR Sebelum dan Sesudah Peristiwa Bom Surabaya

\begin{tabular}{cccccc}
\hline T & AAR Sebelum & T & AAR sesudah & t hitung & sig \\
\hline $\mathrm{t}-5$ & -0.3945055 & $\mathrm{t}+1$ & 1.9745853 & & \\
\hline $\mathrm{t}-4$ & -0.3767253 & $\mathrm{t}+2$ & -0.387904 & & \\
\hline $\mathrm{t}-3$ & -0.4103144 & $\mathrm{t}+3$ & 0.7274352 & -1.71077 & $\mathbf{0 . 0 8 1 1 4 7 *}$ \\
\hline $\mathrm{t}-4$ & -0.3715613 & $\mathrm{t}+4$ & -0.3862153 & & \\
\hline $\mathrm{t}-5$ & -0.7735037 & $\mathrm{t}+5$ & -0.3950514 & & \\
\hline
\end{tabular}

Sumber : Olah Data, Excel 2018

Hasil pengujian statistik dengan mengaplikasikan Paired Sample $t$ test menunjukkan bahwa terdapat perbedaan rata-rata Average Abnormal Return pra dan paska peristiwa pengeboman di Surabaya. Hasil ini mengimplikasikan bahwa peristiwa serangan terorisme memberikan dampak pada rata-rata Abnormal Return emiten manufaktur di pasar modal. Hal ini ditunjukkan secara statistik pada tingkat signifikansi $0,08<$ 0,1 yang menunjukkan bahwa perbedaan rata-rata signifikan pada tingkatan alpha 10\%. Dari nilai AAR $\mathrm{t}+1$ menunjukkan rata-rata abnormal yang sangat positif, menunjukkan bahwa 1 hari setelah serangan bom terorisme respon pasar positif. Investor tidak merasa bahwa serangan terorisme merupakan gangguan yang besar terhadap investasi mereka. Sebagian investor mengambil kesempatan untuk berinvestasi pada sektor manufaktur dikarenakan tidak adanya gangguan langsung yang merugikan dari serangan bom tersebut. Meski resiko politik dan keamanan dapat mempengaruhi pola investor dalam berinvestasi, namun hal ini tidak dirasakan sebagai risiko yang benarbenar mempengaruhi perekonomian.

Tabel 4. Pengujian AAR antar hari sebelum dan sesudah peristiwa Bom Surabaya

\section{$\begin{array}{lllll}\text { Kriteria } & \text { AAR Sebelum } & \text { AAR Sesudah } & \text { t Hitung } & \text { Sig }\end{array}$}

\begin{tabular}{|c|c|c|c|c|}
\hline & Event & Event & & \\
\hline $\mathrm{H}-5$ dan $\mathrm{H}+1$ & -2.32661019 & 1.974585294 & -1.46682 & 0.1905 \\
\hline $\mathrm{H}-4$ dan $\mathrm{H}+2$ & -1.932104653 & 1.586681323 & -1.37135 & 0.1519 \\
\hline
\end{tabular}




\begin{tabular}{lllll}
\hline $\mathrm{H}-3$ dan $\mathrm{H}+3$ & -1.555379359 & 2.314116497 & -1.85788 & 0.1021 \\
\hline $\mathbf{H}-2$ dan $\mathbf{H + 4}$ & $\mathbf{- 1 . 1 4 5 0 6 5 0 0 3}$ & $\mathbf{1 . 9 2 7 9 0 1 2 1 2}$ & $\mathbf{- 1 . 7 6 5 0 4}$ & $\mathbf{0 . 0 7 6 2} *$ \\
\hline $\mathrm{H}-1$ dan $\mathrm{H}+5$ & -0.773503689 & 1.532849793 & -1.13939 & 0.1591 \\
\hline
\end{tabular}

Sumber : Olah Data, Excel 2018

Perbandingan antara hari-hari pra dan paska serangan bom menunjukkan bahwa AAR hari kedua pra kejadian memiliki perbedaan yang signifikan dengan AAR hari ke 4 paska kejadian $(0,07<0,1$, signifikan pada alpha $10 \%)$.

Terlihat nilai AAR paska kejadian memiliki nilai positif, yang menegaskan bahwa pengeboman di Surabaya tidak termasuk bad news yang membuat investor merespon pasar secara negatif.

\section{Reaksi Investor Terhadap Serangan Bom di Surabaya pada 13 Mei 2018}

Pengujian selanjutnya adalah untuk melihat reaksi investor terhadap peristiwa serangan teroris di Surabaya. Pengujian dilakukan dengan melihat nilai Cumulative Average Abnormal Return (CAAR) dari data paska terjadinya serangan bom. Berikut ditampilkan CAAR dari sampel:

Tabel 5. CAAR sesudah peristiwa Bom Surabaya

\begin{tabular}{|c|c|c|c|c|}
\hline T & AAR Sesudah & t & CAAR sesudah & T hitung \\
\hline $\mathrm{T}+1$ & 1.9745853 & $\mathrm{t}+1$ & 1.974585294 & 0.087794833 \\
\hline $\mathrm{T}+2$ & -0.387904 & $\mathrm{t}+2$ & 1.586681323 & -0.12340563 \\
\hline $\mathrm{T}+3$ & 0.7274352 & $\mathrm{t}+3$ & 2.314116497 & 0.066180931 \\
\hline $\mathrm{T}+4$ & -0.3862153 & $\mathrm{t}+4$ & 1.927901212 & -0.12455702 \\
\hline $\mathrm{T}+5$ & -0.3950514 & $\mathrm{t}+5$ & 1.532849793 & -0.12727734 \\
\hline
\end{tabular}

Signifikansi pada 0,01 (T-tabel 1,669)*;

Signifikansi pada 0,05 (T tabel 1,782)**;

Signifikansi pada 0,01 (T tabel 1,675)***

Sumber : Olah Data, Excel 2018

Hasil dari CAAR menunjukkan bahwasanya tidak adanya overreaction paska terjadinya event. Tidak terbukti adanya $\mathrm{t}$ statistik yang signifikan setelah terjadinya event. Hal ini terlihat bahwa fluktuasi AAR paska terjadinya bom dan tidak mengarahkan pada kondisi tertentu yang menegaskan terjadi Overreaction. Untuk lebih jelas dapat dilihat pada grafik dibawah ini:

\section{Grafik CAAR dari sampel}

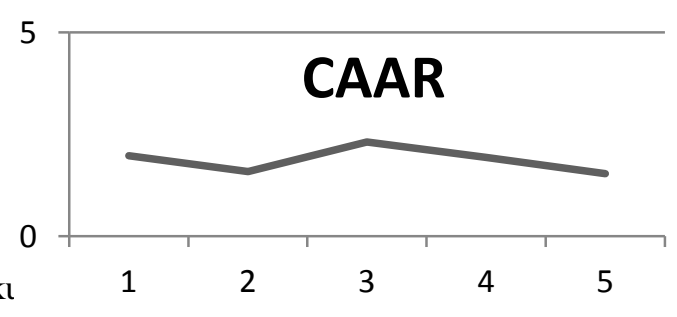


Grafik menunjukkan bahwa return saham perusahaan manufaktur cenderung stabil, dengan peningkatan dan penurunan yang tidak signifikan pada $t+1$ hingga $t+5$, yang menandakan bahwasanya tidak terbukti terjadi overreaction paska kejadian. Hipotesis bahwasanya terjadi overreaction paska terjadinya peristiwa pengeboman ditolak. Ini juga menegaskan bahwasanya investor bereaksi normal terhadap peristiwa yang diduga memberi efek negatif di pasar. Pemboman di Surabaya tidak dapat digolongkan sebagai Bad News di pasar modal, disebabkan tidak memberi dampak negatif pada perdagangan.

\section{KESIMPULAN}

Penelitian ini berupaya untuk menguji efek dari peristiwa serangan terorisme berupa pengeboman yang terjadi di Surabaya pada tanggal 13 Mei 2017 dengan melihat efek yang terjadi melalui perubahan Average Abnormal Return pra dan paska kejadian. Hasil uji statistik beda dua rata-rata menunjukkan bahwa terdapat sentimen positif paska kejadian. Hal ini mengiplikasikan bahwasanya investor tidak merasa bahwa serangan terorisme merupakan gangguan yang besar terhadap investasi mereka. Sebagian investor mengambil kesempatan untuk berinvestasi pada sektor manufaktur dikarenakan tidak adanya gangguan langsung yang merugikan dari serangan bom tersebut. Perbandingan antara hari-hari pra dan paska serangan bom menunjukkan bahwa AAR hari kedua pra kejadian memiliki perbedaan yang signifikan dengan AAR hari ke 4 paska kejadian menunjukkan bahwa peristiwa pengeboman tidak termasuk sebagai bad news bagi pelaku pasar modal. Reaksi investor terhadap peristiwa serangan bom dilakukan dengan melihat nilai Cumulative Average Abnormal Return (CAAR) dari data paska terjadinya serangan bom dan menunjukkan bahwa return saham perusahaan manufaktur cenderung stabil, dengan peningkatan dan penurunan yang tidak signifikan pada $t+1$ hingga $t+5$, yang menandakan bahwasanya tidak terbukti terjadi overreaction paska kejadian.

Penelitian ini dilakukan dengan beberapa keterbatasan, salah satunya hanya menyertakan sampel perusahaan manufaktur yang ada di BEI. Pengeboman yang dilakukan oleh teroris pada tanggal 
13 Mei 2017 merupakan bentuk dari risiko politik dan keamanan, namun tidak secara langsung berimbas pada kegiatan usaha manufaktur di Indonesia. Lebih lanjut, pengujian dilakukan dengan event window tanpa mempertimbangkan estimation period, sehingga cenderung memberikan efek bias pada perhitungan abnormal

\section{DAFTAR PUSTAKA}

Aurangzeb, I \& Dilawer, T. 2012. Impact of Terrorism on Stock returns: Evidence from Pakistan. Universal Journal of Management and Social Sciences, 2(8), 7385.

Baker, D.M.A. (2014). The Effects of Terrorism on the Travel and Tourism Industry. International Journal of Religious Tourism and Pilgrimage, 2(1), 57-67.

Baker, M., \& Wurgler, J. (2006). Investor Sentiment and the Cross-Section of Stock Returns. The Journal of Finance, 61(4), 1645-1680.

Bodie, et al. 2011. Investment and Portofolio Management. McGraw-Hill

DeLong, J. B., Shleifer, A., Summers, L.A., \& Waldmann, R.J. 1990. Noise Trader Risk in Financial Markets. Journal of Political Economy, 98(4): 703-38.

Fama, E.F. (1970). Efficient capital market: a review of theory and empirical work. Journal of Finance 25, 383 - 417.

Handadari, Cahyaning. 2003. Reaksi Harga Saham di Bursa Efek Jakarta terhadap Peledakan Bom Bali di Bali tanggal 12 Oktober 2002. Skripsi. Universitas Sebelas Maret Surakarta. return pra kejadian. Peristiwa Pengeboman bukanlah kejadian yang dapat di prediksi atau di rencanakan, sehingga perlu adanya estimasi yang lebih panjang untuk melihat return saham perusahaan dan stabilitas tingkat pengembalian pada periode yang lebih panjang sebelum kejadian.

Handoko, W. M. W \& Supramono (2017), Sentimen Investor Terhadap Peristiwa Terorisme Berbasis Fundamental Perusahaan (Studi pada Peristiwa Serangan Bom Sarinah 14 Januari 2016), Jurnal Akuntansi dan Keuangan, Vol.19 No.2

Johnston, R.B., \& Nedelescu, O.M. 2005. The Impact of Terrorism on Financial Markets. IMF Working Paper.5.1-22.

Kumar, S., \& Liu, J. 2013. Impact of Terrorism on International Stock Markets. Journal of Applied Business and Economics, 14(2), 42-60.

Mehrani, K, Roodposhti, F.R, Nekomaram, H., and Saedi, A. 2016. Behavioral trading strategies and investor sentiment: Empirical research in Tehran Stock Exchange (TSE). Indonesian Capital Market Review, 8, 94109.

Najaf, R. (2017). Effect of Terrorism on the International Business in Pakistan. Journal of Accounting \& Marketing, 6(1), 1-3.

Sartono, Agus. 2009. Manajemen Keuangan: Teori dan Aplikasi. BPFE. Yogyakarta.

Sirait, R.S., \& Tiswiyanti, W, Mansur, F. (2012). Dampak Pergantian Menteri Keuangan RI Tahun 2010 terhadap 
Abnormal Return Perusahaan Perbankan yang Terdaftar di BEI. e-Jurnal Binar Akuntansi, 1(1), 14-22.

Utama. C. A \& Hapsari. L, 2012. Jenis Industri, Kepemilikan Saham Asing dan Reaksi Pasar Modal Akibat Serangan Bom Teroris, Jurnal Akuntansi dan Keuangan Indonesia, 9:2

Verawaty \& Pratiwi. R., 2016, Fluktuasi Harga Saham Perusahaan Manufaktur Yang Terdaftar di BEI Pasca Tragedi Ledakan Bom Sarinah, Jurnal Ilmiah MBiA. 15:1.

$\underline{\text { www.sahamok.com }}$

www.finance.yahoo.com 